\title{
İş-Aile ve Aile-İş Çatışması, İş, Aile ve Hayat Tatmininin İşten Ayrılma Niyeti Üzerine Etkisi: Karşılıklı ve Demografik Değişkenli Etkileșimler*
}

\author{
Özden AKIN ${ }^{1}$ \\ Hüseyin KARAKULAK ${ }^{2}$
}

ÖZ: Yoğun ve hassas görevleri olan hastane çalışanlarının iş ve aile sorumlulukları çatışma yaratmakta, iş, aile ve hayat tatmini işten ayrlma niyetine yol açabilmektedir. Çalışmanın amacı iş-aile çatışması, aile-iş çatışması, iş tatmini, aile tatmini, hayat tatmini ve işten ayrılma niyeti ilişkisini ortaya koymaktır. Veriler anket tekniği yoluyla bir Üniversite hastanesindeki hemşire, sağllk ve veri kayıt memurlarından toplanmış ve oluşturulan model Yapısal Eşitlik Modeliyle test edilmiştir. İş-aile, aile-iş çatışmasının işten ayrlma niyetine olumlu ve iş tatminine olumsuz etkisi anlamlı çımıştır. Ayrıca değiş̧kenler arası ilişkilerde demografik değişken ve tatmin ve çatışma değişkenlerinin rolünün olup olmadığına yönelik etkileşim analizleri yapılmış, anlamlı sonuçlar bulunmuştur.

Anahtar Kelimeler: $\dot{I}_{S ̧}$-Aile Çatış̧ması, İş Tatmini, Aile Tatmini, İşten Ayrılma Niyeti JEL Sinıflaması: D23, M12; L2

\section{The Effects of Work-Family and Family-Work Conflict, Job, Family and Life Satisfaction on Intention to Leave: Mutual and Demographic Variables Interactions}

\begin{abstract}
The job and family responsibilities of hospital employees with intensive and sensitive tasks can create a conflict job, family and life satisfaction lead to intention to leave of job. The aim of the study is to reveal the relationship between work-family conflict, family-work conflict, job satisfaction, family satisfaction and life satisfaction and intention to leave. Data were collected from nurses, health and data registrars in a University hospital through questionnaire technique and the model was tested with Structural Equation Model. The positive effect of job-family, family-job conflict on intention to leave and negative effect on job satisfaction was significant. In addition, a negative and significant relationship was found between job satisfaction, intention to leave, family satisfaction and intention to leave, life satisfaction and intention to leave. In addition, interaction analyzes were conducted to determine whether demographic variable and satisfaction and conflict variables had a role in the relationships between variables, and significant results were found.
\end{abstract}

Keywords: Work-Family Conflict, Job Satisfaction, Family Satisfaction, Intention to Leave JEL Codes: D23; M12; L2

\footnotetext{
* Bu çalışma Hüseyin Karakulak'ın Hatay Mustafa Kemal Üniversitesi Sosyal Bilimler Enstitüsü İşletme Ana Bilim Dalında 2019 yılında hazırlanıp savunulan "İş-Aile ve Aile-İş Çatışması ile İşAile-Hayat Tatmininin İşten Ayrilma Niyeti Üzerine Etkisi: Bir Üniversite Hastanesinde Araştırma" başlıklı Yüksek Lisans tezinden üretilmiştir.

1 Dr. Öğr. Üyesi, Hatay Mustafa Kemal Üniversitesi, İ̈BF, ozdendogan@gmail.com, orcid.org/0000-0002-8459-9334

${ }^{2}$ Hatay Mustafa Kemal Üniversitesi, h_karakulak@ hotmail.com, orcid.org/0000-0002-7126-7816
} 


\section{Giriş}

Çalıșma yaşamında iş ve aile sorumluluklarının yerine getirilmeye çalıșılması önemli, ancak zordur. İş ve ailenin gerektirdiği sorumluluklar, gerek iş gerekse aile yaşantısı içerisinde çatışma yaratmakta ve çalışanlar üzerindeki etkileri olumsuz olabilmektedir (Hennessy, 2005). Örgütsel açıdan çatışma kavramı, çalışanların temel anlamda işlerinde yaşadıkları bir problem durumudur (Aslan, 2004). Modern toplumlarda çalışanların gerek iş gerekse aile çatışmaları ve bu çatışmalardan ortaya çıkan stres durumu düşük moral ve verimlilik, sağlık sorunları ve işten ayrılma niyeti gibi olumsuz durumlara yol açmakta ve işletmelerin maliyetini ciddi oranda arttırmaktadır (Edwards ve Rothbard, 2000). İş-aile çatışması, çalışanların işyerindeki tutum ve davranışlarını da olumsuz etkileyebilmekte, çalışanların iş tatmin düzeyi ve performansı azalmakta, işyerindeki düzensiz çalışma saatleri de bu durumu arttırabilmektedir. Daha sonraki aşamalarda iş tatmini düştükçe, çalışanın işten ayrılma niyeti artmaktadır (Judge ve Watanabe, 1993; Yüksel, 2005:305).

Hizmet sektörü çalışanları, müşteri memnuniyetini sağlamak amacıyla iş hayatının birçok olumsuz etkisine maruz kalabilmektedir. Aynı zamanda çalışanların yoğun iş ortamı içerisinde olumsuz tutum ve davranışları daha da artabilmektedir (Turunç ve Erkuş, 2010: 416). Özellikle sağlik sektörü çalışanları hem yoğun iş sorumlulukları hem de aile sorumluluklarıyla mücadele etmektedirler. Bu mücadele uzun çalışma saatleri, ağır iş yükü, düşük ücret ve ağır hastalara bakma gibi koşullarda daha da artmaktadır (Wong ve Ko, 2009). Ağır iş yükü altında aile yükümlülüklerini yerine getirememe durumu işten ayrılma niyetine kadar gidebilmektedir. Bu çalışmanın amacı iş-aile ve aile-iş çatışması, iş, aile ve hayat tatmininin işten ayrılma niyeti üzerindeki etkilerini belirlemek ve işten ayrılma ve iş tatmini üzerindeki etkilerde bu değişkenler ile demografik değişkenlerin etkileşim durumlarını ortaya koymaktır.

\section{Kavramsal Çerçeve}

\section{1. İş-Aile ve Aile-iş Çatışması}

Akademik alanda yapılmış çalışmalarda iş ve aile çatışmasının, iş-aile ve aile-iş çatışması olmak üzere iki yönü olduğu ve bu iki kavramın birbiri ile ilişki halinde olduğu ifade edilmektedir (Netemeyer vd., 1996: 400). İş hayatındaki sorumluluklar aile yaşantısındaki sorumlulukları, aile hayatına ilişkin sorumluluklar da iş hayatını etkilemekte (Özdevecioğlu ve Doruk, 2009) bu da iki ayrı gibi gözüken hayatın karşılıklı çatışmasına neden olmaktadır.

İş-aile çatışması, iş ve aile rollerinin aynı zamanda üstlenilmesi ve iki rolün iç içe girmesi ve çatışması durumunda ortaya çıkan bir uyumsuzluk durumudur (Greenhaus ve Beutell, 1985: 77; Lu vd., 2005). İş-aile ve aile-iş çatışması, iş ve aile yaşamının birbiriyle çelişen isteklerinin yarattığ 1 uyuşmazlık ve bu rollerin dengelenmemesi sonucunda ortaya çıkabilmektedir (Yüksel, 2005). Cazan vd. (2019) aile hayatı ve iş hayatı arasında geçirgen bir sınır bulunduğunu ve aralarında 
etkileşime olanak verdiğini bu durumun da çalışanların her iki hayatında olumlu ve olumsuz sonuçlara yol açabileceğini söylemektedirler. İş-aile çatışması Kahn vd. (1964) tarafından rol çatışması ve roller arası çatışmaya dayanarak açıklanmıştır. Kişinin üstlendiği rol sebebiyle sergilemek durumunda olduğu tutum ve davranışların, kişinin üstlendiği diğer rol ya da rollerin gerektirdiği tutum ve davranışlarla uyumsuzluk göstermesi durumunda çatışma yaşanmaktadır. Hennessy'e (2005) göre iş-aile çatışması; çalışanın üzerindeki iş sorumluluklarının, ailedeki sorumluluklarını gerçekleştirmesini engellemesi sonucu ortaya çıkan çatışmalardır. İşle ilgili sorunlar; yoğun çalışma saatleri, iş seyahatleri ve evde çalışma durumu gibi durumlar yaşandığında ortaya çıkabilmektedir.

Aile-iş çatışması, çalışanın aile içindeki rollerinin, iş ile ilgili rollerini yerine getirmesini engellediğinde meydana gelmektedir (Turgut, 2011: 159). Aileden kaynaklı olan bu çatışmada, çalışanın aile yaşam alanlarındaki sorumluluklarıyla iş alanındaki sorumlulukları çatışmaktadır. Wayne vd. (2004), aile iş çatışmasını "birinin aile rolünden onun iş rolüne negatif müdahale etmesi" olarak açıklamıșlardır. Bu tanım, aile ile ilgili rolün diğer role olumsuz olarak yansıması ve gerekli başarıyı ve tatmini yakalayamaması anlamına gelmektedir. Özdevecioğlu ve Doruk (2009) ise aile-iş çatışmasını kişinin aile rolü gereği işin sorumluluklarını yerine getirememesi şeklinde tanımlamıştır. Aileden işe yönelik oluşan çatışmanın temelinde aile ile ilgili konular ve problemler gelmektedir. Çocuklarla ve ev ile ilgili yerine getirilmesi gereken sorumluluklar yüzünden işe gidemeyen çalışanlar aile-iş çatışması yaşayabilmektedirler (Büyükyılmaz ve Akyüz, 2015; Yüksel, 2005: 304). Bu problemler içerisinde, eş desteğinin olmaması, eşle ilgili yaşanan problemler ve anlaşamama, aile ile ilgili geçirilen zamanın az olması ve faaliyetlere katılamama, çocuk sayısı ve yaş gibi nedenler yer almaktadır (Cinamon, 2006: 2). Wang ve Peng (2017) çalıșanların iș veya aile talepleri nedeniyle aileleri için sorumluluk almakta zorlandıklarını ya da ağır aile sorumlulukları nedeniyle iş ile ilgili sorumluluklarını yerine getiremez duruma geldiklerini söylemektedirler. Bu durumda bir taraftaki talepler kişi üzerinde baskı yaptığında, diğer taraftaki sorumlulukları yerine getirmede sıkıntı yaratabilmektedir.

\section{2. İş Tatmini, Aile Tatmini ve Hayat Tatmini}

İş tatmini, çalışanın işi ve iş yerindeki çalışma koşullarından duyduğu memnuniyet, ikisi arasındaki uyum ve dengeyi yakalaması sonucu meydana gelen memnun edici bir duygu durumu halidir ve çalışan işine karşı olumlu bir tutum geliştirmişse iş tatmini de gerçekleşmiştir denilmektedir (Ugboro ve Obeng, 2000: 254). İş tatmini diğer taraftan, bireylerin hem bedensel ve zihinsel sağlıklarının hem de fizyolojik ve ruhsal duygularının göstergesidir. İş tatmini, çalışanın işten elde ettiği gelire ek olarak çalışmaktan zevk aldığı ekip arkadaşları ile birlikte iş yapmanın çalışana sağladığı mutluluk şeklinde de tanımlanabilir (Şimsek vd., 2003: 150). Locke (1976) iş tatminini, çalışanın işini ve iş hayatındaki tecrübelerini değerlendirmesi sonucunda oluşan olumlu veya zevkli hisler şeklinde tanımlamıştır. Başka bir 
tanımlamada iş tatmini, bireyin işine karşı beklediği veya arzuladığı sonuçlarla gerçekleşen sonuçlar arasında yaptığı karşılaştırmalar sonucunda oluşan duygusal tepkilerdir (Cranny vd., 1992). İş tatmini bir çalışanın, iş tecrübesini etkili ve/veya bilişsel olarak değerlendirmesinden kaynaklanan olumlu veya olumsuz duyguların bir dereceye kadar içsel halidir (Brief vd., 1998).

İş tatmini çalışanların işlerini sevmeleri veya sevmemeleri durumudur. İş tatminini en çok belirleyen değişkenler ise ücret, ilerleme firsatları, meslektaşlar, yöneticiler ve işin kendisi gelmektedir. İş tatmini içsel ve dişsal iş tatmini olarak ikiye ayrıldığında iş tatmini ve hayat tatmini arasındaki ilişkinin gücünü belirlemek daha anlamlı olacaktır. Dışsal iş tatmini olarak değerlendirilebilecek iş ile ilgili çıktılar alınan ücret ve prestij olarak değerlendirilirse bu çıktıların hayat tatminine olan katkısı da yüksek olacaktır. İçsel iş tatmini ise kişinin işine verdiği değeri ifade eder ve işine değer veren kişinin hayat tatmini de bundan etkilenecektir. Bu anlamda iş ile hayat tatmini arasında güçlü bir ilişki bulunmaktadır (Rice vd., 1980; Özdevecioğlu ve Doruk, 2009; Steiner ve Truxillo, 1987).

Aile tatmini, çalışanların aile hayatlarıyla ilgili olarak pozitif veya negatif yöndeki algılamalarının yansıması olarak ifade edilmektedir. Çalışanın pozitif algısı, memnuniyetinin yüksek olduğunu gösterirken, negatif algısı ise düşük düzeyde memnuniyet göstergesi olarak ifade edilmektedir (Ji vd., 2002). Aile tatmini Pattusamy ve Jacob (2017) tarafından kişinin genel olarak aile ile ilgili yönünü değerlendirmesinden kaynaklanan duygusal bir durum olarak tanımlanmaktadır. Aile tatmini, bireylerin yaşam kalitesinin önemli bir unsuru olarak kabul edilmekte ve hayattan alınan tatmini de etkilemektedir (Diener ve Lucas, 1999). Çalışanların işleri ile ilgili sahip olduğu rol ve sorumluluklar aile yaşantısını ve sorumluluklarını, aile ile ilgili rol ve sorumlulukları ise iş yaşamını ve başarısını olumlu veya olumsuz yönde etkileyebilmektedir (Kiecolt, 2003). Ford vd. (2007) çalışmalarında aile tatmininin iş ve aile stresi, iş-aile çatışması üzerinde önemli etkileri olduğunu ortaya çıkarmışlardır. Stolzenberg (2001) çalışmasında erkek çalışanların işyerinde uzun çalışma saatleri geçirmesi sebebiyle hem sağlık durumlarının etkilendiğini hem de aile üyelerine daha az zaman ayırdığını söylemiştir. Çalışanların iş tatmin düzeylerinin yalnızca iş ve aile ile ilgili faktörlere bağlı olduğunu söylemek yeterli değildir. Genel olarak iş tatmini, hayat tatmini ve aile tatmini ilişkilerinde birbirleri arasındaki etkileşimini incelemek daha anlamlı olacaktır. İş tatmininin, performans, büyüme hızı, verimlilik gibi unsurlarla birlikte örgütün başarısını etkileyen önemli bir faktör olduğu ifade edilmektedir. İş tatmininin, hayat tatmini üzerinde, hayat tatmininin de iş tatmini üzerinde karşılıklı etkileşimde olduğu söylenmektedir (Aydemir ve Erdoğan, 2013).

Hayat tatmini, bir insanın elinde olanlarla (neye sahip olduğu) beklentilerinin (ne istediği) karşılaştırılması sonucunda ortaya çıkan durum ya da sonuç olarak ifade edilmektedir (Özer ve Karabulut, 2003: 72). Heller vd. (2004) hayat tatminini, bireyin kendi yaşamının kavramsal bir yargısı ya da değerlendirmesi sonunda oluşan bir tutum olarak tanımlamışlardır. Hayat tatmini kişinin hoşlandığ 1 ya da 
hoşlanmadığı yönlerinin kısa bir değerlendirmesidir. Hayat tatmini genellikle yaşamı değerlendirmenin sonucunda bireyin genel refahını ifade etmektedir (Karatepe, 2008). Bu genel refahı yansitan göstergeler, bireyin fiziksel ve maddi refahı, kişilerarası ilişkiler, sosyal aktiviteler gibi bireysel yaşam kalitesini yansıtan göstergelerdir (Johansson ve Bernspang, 2003). Dockery (2004: 2), hayat tatminine etki eden faktörleri özgürlük ve demokrasinin kabul gördüğü ekonomik açıdan zengin bir ülkede yaşamak, politik istikrarlılık, azınlığın değil çoğunluğun bir parçası olmak, toplumdaki sosyal katmanın üst gruplarında yer almak, evli olma durumu, aile ve arkadaşlarla iyi ilişkilerde bulunmak, sağlam bir fiziksel ve ruhsal duruma sahip olmak, aktif ve açık fikirli olmak, hayatının kontrolünün, kendinde olduğunu hissetmek, para kazanma ve politik olarak tutucu olmak yerine, sosyal ve moral açısından güzel değerlere sahip olmaya karşı isteklilik şeklinde belirlemiştir.

\section{3. İşten Ayrılma Niyeti}

Birçok çalışma işten ayrılma niyetini daha çok işyerindeki tatmin duygusuna bağlamış (Çekmecelioğlu, 2005: 28) olup iş, aile veya kişisel nedenler (Kurtulmuş ve Karabıyık, 2016: 1328) gibi genel hayat tatmini ile ilgili faktörlere çok az yer verilmiştir. Hâlbuki çalışanların yaşamları yalnızca işyerinde değil dışarda da geçmekte olup genel yaşamla iş yaşamı iç içe ve karşılıklı ilişki halindedir. Yıldız vd., (2013) işten ayrılma niyetini, "kişinin başka iş seçeneklerini değerlendirmek için, şu anki işinden ayrılmak istemesi" şeklinde tanımlamışlardır. Kinnie vd., (1998) çalışanların işten çıkarılma düşüncesiyle yaşadıkları stres sebebiyle işten ayrılma düşüncelerinin arttığını bildirmiştir. İşten atılma korkusu yaşayan çalışanlar, işe gelme isteklerindeki azalmaya bağlı olarak iş kalitesini düşürmekte ve daha az çalışarak başka iş arayışına girebilmektedir. Bartlett (2001) işten ayrılma niyetini, örgütten ayrılma konusunda dikkatli ve bilinçli bir karar veya niyet olarak tanımlamıştır. Shahpouri vd.'ne göre (2016), işten ayrılma niyeti çalışanların gerçek ayrılmadan önceki son aşamasıdır ve bu durum işletmeler için zararlı sonuçlara, büyük maliyetlere neden olmaktadır. İşten ayrılma niyetini psikolojik bir süreç olarak tanımlayan Akbolat vd., (2014) bu süreci kişinin mevcut işiyle ilgili genel değerlendirmesi ve işinin doyumsuzluk derecesi, diğer işlerin daha cazip gelmesi ve ulaşılabilirliğinin değerlendirilmesi, ayrılma niyetinin bazı ifadeleri, işten ayrılma kararı şeklinde sıralamakta ve bu şekilde geliştiğini ifade etmektedirler.

\section{Araştırmanın Hipotezleri ve Modeli}

Genel olarak, aile-iş çatışmasına kıyasla iş-aile çatışması konusu daha fazla irdelense de (Netemeyer vd., 1996) bu iki kavram karş1lıklı pozitif anlamlı bir ilişkiye (Hasyurt, 2017) sahiptir. Özdevecioğlu ve Doruk (2009) yaptıkları çalışmada da iş-aile ve aile-iş çatışması arasında pozitif yönlü bir ilişki bulmuşlardır. Buna göre geliştirilen hipotez aşağıdaki gibidir:

H1: İş-aile çatışması ile aile-iş çatışması arasında pozitif yönlü bir ilişki vardır. 
İş-aile çatışmasının iş üzerinde önemli ve negatif etkiye sahip olduğunu, aile-iş çatışmasının da çalışanlar üzerinde genel sağlık ve mutluluğu olumsuz yönde etkilediğini söylemişlerdir (Heller vd., 2002). Burke (1988) iş ve aile arasındaki konuların birbirinin içine geçme durumunun çalışanlarda yüksek düzeyde olmasını psikolojik yıldırma ve işe yabancılaşma ve daha az iş tatmini olarak belirlemiştir. Judge ve Watanabe (1993) iş, aile ve hayat tatmini kavramları arasında güçlü bir ilişki olduğunu ve karşılıklı olarak birbirlerini etkilediklerini söylemektedirler. Buna göre bu çalışmada geliştirilen hipotez aşağıdaki gibidir:

H2: İş tatmini ile aile tatmini arasında pozitif yönlü bir ilişki vardır.

Literatür, hayat iş tatmini arasındaki gözlemlenen ilişkiyi açıklamak için üç farklı kuramsal bakış açısı sunmaktadır. Bu bakış açıları, iş tatminini hayat tatminine bağlayan ast-üst bakış açısı (Brief vd., 1993), iş tatminini etkileyen hayat tatmini olarak yukarıdan aşağıya olan bakış açısı (Judge ve Watanabe, 1993) ve son olarak da çevresel ve ruhsal faktörlerin hem iş hem de hayat tatminini etkilediğini iddia eden (Judge vd., 1997) çevresel ve ruhsal bakış açısıdır. Bu anlamda iş tatmini üzerinde hayat tatmininin de temel etkileri olduğu söylenmektedir $(\mathrm{Qu}$ ve Zhao, 2012). İş ve hayat tatmini arasında pozitif yönlü ve güçlü bir ilişki olduğu ve birbirlerini karşılıklı olarak etkilediği tespit edilmiştir (Heller vd., 2002; Judge ve Watanabe, 1993). Heller vd. (2002) çalışmalarında kişisel özelliklerin hem iş hem de hayat tatmini üzerindeki etkilerini test etmişlerdir.

Qu ve Zhao (2012) ve Adams vd. (1996) yaptıkları çalışmada hayat tatmininin iş tatminiyle pozitif yönde ilişkili olduğunu tespit etmişlerdir. Hayat tatmini ve iş tatmini ilişkisini hastane çalışanları üzerinde inceleyen Karatepe (2008), iş ve hayat koşullarının zor ve hassas olması sebebiyle, hastane çalışanlarının iş ve aile arasındaki dengeyi kurmakta zorluklar yaşadıklarını ifade etmiştir. Bireylerin hayat tatminini etkileyen faktörleri Keser (2005) yaşamı anlamlı bulmak, pozitif yönlü bireysel kimlik, fiziksel açıdan iyi olma durumu, ekonomik, güvenlik ve sosyal ilişkiler, günlük hayattan mutluluk duymak, amaçlara ulaşma konusundaki uyum şeklinde ifade etmişlerdir. Düşük hayat tatmini göstergelerinin yüksek çatışma ve düşük iş tatmini ile önemli derecede ilişkili olduğu, iş tatmininden hayat tatminine pozitif yönde bir yayılmayı ve geçişi destekleyen bulgular ortaya çıkmıştır (Adams vd., 1996; Higgins ve Duxbury, 1992). Aile tatmini gerek bireysel gerekse toplumsal olarak insan hayatı için önemlidir. Aile tatmini ile ilgili yapılmış çalışmalar iş ve hayat tatminine göre kısıtlı olmakla beraber, aile tatmini ile ilgili farklılıkların iş ve hayat tatmini ile ilişkili olduğu söylenmektedir (Karabay, 2015). (Lee vd., 2018: 868) çalışanların işlerinde yaşadıkları iş tatmini ve iş yaşamı kalitesi gibi pozitif deneyimlerin genel hayat tatminleri ve mutlulukları üzerinde pozitif etki yarattıklarını tespit etmişlerdir. Buna göre geliştirilen hipotezler aşağıdaki gibidir:

H3: İş tatmini ile hayat tatmini arasında pozitif yönlü bir ilişki vardır.

H4: Aile tatmini ile hayat tatmini arasında pozitif yönlü bir ilişki vardır. 
Qu ve Zhao (2012) iş-aile çatışmasının farklı durum ve koşullarda iş tatmini ve hayat tatmini üzerinde etkisini araştırmışlardır. Sonuçlar, iş ve aile arasında daha az çatışma yaşayan çalışanların günlük yaşamdan işyerine olumlu yönler taşıma eğiliminde olduklarını göstermektedir. Karimi (2008) çalışmasında iş-aile çatışmasının iş tatmini üzerinde önemli ve negatif etkiye sahip olduğunu bulmuştur. Turunç ve Erkuş (2010), bankacılık sektöründe yaptıkları çalışmada örgüt çalışanlarının yaşadığ doğrudan ve negatif olarak etkilediğini göstermiştir. Tekingündüz vd. (2016) hemşireler üzerinde yaptıkları çalışmada, iş tatmini ile iş-aile çatışması arasında negatif yönlü bir ilişki bulmuşlardır. Büyükyılmaz ve Akyüz (2015) turizm sektörü çalışanları üzerinde yaptıkları çalışmada iş-aile çatışmasının iş tatminini negatif ve anlamlı olarak etkilediğini göstermişlerdir. Raza vd. (2018) kamu ve özel hastanelerde sağlık çalışanları üzerine yaptıkları çalışmalarında iş-aile dengesinin sağlandığı durumlarda iş tatmininin arttığını tespit etmişlerdir. İş ve aile çatışması yaşandığında ikisi arasındaki dengeyi korumanın zorlaştığını söylemişlerdir. Buna göre geliştirilen hipotez aşağıdaki gibidir:

H5a: İş-aile çatışması ile iş tatminini arasında negatif ilişki vardır.

İş-aile çatışmasının hem iş hem de aile yaşamı kalitesi üzerinde önemli etkiye sahip olduğu söylenmektedir. İş-aile ilişkisinin karşılıklı olarak birbirlerini etkilediği açık bir şekilde görülmektedir (Greenhaus ve Beutell, 1985). Bu durum işin aile ile ailenin de iş ile birbirine karıştığını göstermektedir. Ancak genel olarak yapılan çalışmalar iş-aile çatışmasının aile-iş çatışmasından daha yaygın olduğunu göstermektedir (Frone vd., 1992). Aile hayat kalitesinin önemli bir parçası olan aile tatmini birey için önemli bir alan olduğundan yaşamdan duyulan tatmini etkilemektedir. Coşkuner (2013) yapmış olduğu çalışmasında evlilik, aile ve hayat tatmini ilişkisinde iş ve aile çatışmasının aracı rolü oynayıp oynamadığını tespit etmeye çalışmıştır. Ulaştığı sonuçlara göre iş-aile çatışması evlilik, aile ve hayat tatminini azaltmakta ve olumsuz etkilemektedir. Buna göre geliştirilen hipotez aşağıdaki gibidir:

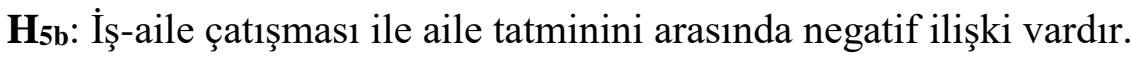

İş-aile çatışmasının iş tatmini ve hayat tatmini üzerinde işin aileye veya ailenin işe müdahale edip etmediği ve ikisinin aracılık rolü olup olmadığ incelenmektedir $(\mathrm{Qu}$ ve Zhao, 2012). Siegel vd., (2005) çalışanların güçlü derecede iş-aile ve aile-iş çatışması yaşadıklarında işe olan katkısının ve genel olarak da yaşam kalitesinin ya pozitif ya da negatif yönde etki ettiğini söylemektedir. Ayrıca, bireyler iş ve aile dengesini sağlamada yeterli yeteneğe sahip olmadığında, öncelikle aile hayatlarını düzenleme eğiliminde oldukları görülmektedir (Frone vd., 1992). Yüksek iş-aile çatışması ve aile-iş çatışması bireyler üzerinde negatif olumsuz duygularla sonuçlanmakta ve bu olumsuz durum hayat tatmininden iş tatminine doğru yayılmaktadır. İş-aile ve aile-iş çatışma düzeyine bağlı olarak değişkenlik göstermektedir (Ilies vd., 2009). İş-aile ve aile-iş çatışması düzeyi yüksek olduğunda çalışanların olumsuz hissi hayat tatmininden iş tatminine doğru 
yansıyacaktır ve dolayısıyla iş tatmininin de negatif olmasına sebep olacaktır. İşaile çatışması ile aile-iş çatışması düşükse olumlu duygular hayattan işe doğru yansıyacak ve pozitif olacaktır (Qu ve Zhao, 2012). Özdevecioğlu ve Doruk (2009) çalışmalarında çalışanların iş-aile ve aile-iş çatışmalarının hayat tatminlerini olumsuz etkilediğini göstermiş ve aralarındaki ilişkiyi negatif yönlü bulmuşlardır. Buna göre geliştirilen hipotez aşağıdaki gibidir:

H5c: İş-aile çatışması ile hayat tatminini arasında negatif ilişki vardır.

Örgüt çalışanlarında görülen aileden kaynaklı sorunların işe yansıması önemli sorunlar yaratabilmektedir. Tekingündüz vd., (2016) sağlık sektöründe hemşireler üzerinde yaptıkları çalışmada aile-iş çatışması ve iş tatmini arasında diğer çalışmanın aksine negatif yönlü bir ilişki bulmuşlardır. Büyükyılmaz ve Akyüz (2015), turizm sektörü çalışanları üzerinde yaptıkları çalışmada aile-iş çatışmasının iş tatmini üzerinde de negatif yönlü ve anlamlı bir etkiye sahip olduğunu bulmuşlardır. Türker ve Çelik (2019) çalışmalarında aile-iş çatışmasının iş tatmini üzerinde doğrudan bir etkisi olmadığını tespit etmişlerdir. Karabay (2015) aile-iş çatışmasının hayat tatmini üzerine etkisinin hem doğrudan hem de dolaylı olduğunu ve iş-aile çatışmasına kıyasla daha az etkili olduğunu söylemektedir. Buna göre geliştirilen hipotezler aşağıdaki gibidir:

H6a: Aile-iş çatışması ile iş tatminini arasında negatif ilişski vardır.

H6b: Aile-iş çatışması ile aile tatminini arasında negatif ilişki vardır.

Hoc: Aile-iş çatışması ile hayat tatminini arasında negatif ilişki vardır.

İş-aile çatışmasının sonucunda çalışanların olumsuz iş tutumları sergilediği, buna bağlı olarak da düşük iş tatmini ve yükssek işten ayrılma niyeti oluştuğu görülmektedir (Cohen, 1997; Özbağ ve Ceyhun, 2014). Bunun nedeni iş yükünün ağırlaşması, sıkıntı ve strese bağlı olarak, iş ile aile arasındaki yaşantıda gerilime yol açmasıdır (Cohen, 1997). Çalışanlar iş ve aile sorumlulukları arasındaki dengeyi kuramadıklarında çatışma durumunu azaltmak için işten ayrılma alternatifini düşünmektedirler (Rode vd., 2007). Çarıkçı ve Çelikkol (2009) bir imalat sektöründe yaptıkları çalışmada örgüt çalışanlarının iş ve ailedeki rolleri ile ilgili olarak karşılaştıkları çatışmanın örgütsel bağlılıklarını ve işten ayrılma düzeylerini pozitif yönde arttırdığını söylemişlerdir. Hasyurt (2017), iş-aile çatışmasının işten ayrılma niyeti üzerine etkisini incelediği çalışmasında iş-aile çatışması ve aile işten ayrılma niyeti arasında herhangi bir ilişki bulamamış, ancak aile-iş çatışması ile işten ayrılma niyeti arasında pozitif yönlü bir ilişki bulmuştur. Buna göre geliştirilen hipotezler aşağıdaki gibidir:

H7: İş-aile çatışması işten ayrılma niyetini pozitif yönde etkilemektedir.

H8: Aile-iş çatışması işten ayrılma niyetini pozitif yönde etkilemektedir.

Özbağ ve Ceyhun (2014) iş-aile çatışması, iş tatmini ve işten ayrılma niyeti arasındaki ilişkiyi Türkiye'de bir havayolları işletmesinde incelemişlerdir. İş 
tatmininin önemli bir aracı etkisi olduğunu iddia etmiş ve iş-aile çatışmasının işten ayrılma niyeti üzerinde pozitif etkiye sahip olduğunu bulmuşlardır. İş tatmininin işten ayrılma niyeti üzerinde negatif etkiye sahip olduğunu söylemişlerdir. Özbağ ve Ceyhun (2014) çalışmalarında iş tatmininin işten ayrılma niyeti üzerinde negatif etkiye sahip olduğunu tespit etmişlerdir. Rode vd., (2007) iş ve hayat tatmini, işaile çatışması ve işten ayrılma niyeti arasında ilişki olduğunu iddia etmektedirler. İş ve hayat tatmininin iş-aile çatışması değişkenleri arasında negatif yönlü ilişki olduğunu söylemektedirler. Ayrıca iş ve hayat tatmininin işten ayrılma niyeti ile negatif ilişkili olduğunu iddia etmişlerdir. Geliştirilen hipotezler aşağıdaki gibidir:

H9: İş tatmini işten ayrılma niyetini negatif yönde etkilemektedir.

H10: Hayat tatmini işten ayrılma niyetini negatif yönde etkilemektedir.

H11:Aile tatmini işten ayrılma niyetini negatif yönde etkilemektedir.

Yukarıda belirtilen hipotezlerin testinin SEM'de yapılmasına yönelik geliştirilen model Şekil 1'de ki gibi oluşturulmuştur. Modelin testi sırasında kontrol değişkenleri olarak cinsiyet, medeni durum, çocuk sayısı, yaş, eğitim, meslek, statü ve toplam çalışma süresi işten ayrılma niyetine olan etkisi olarak eklenmiştir. Çalışmada, iş-aile, aile-iş çatışması, iş, aile, hayat tatmini ve işten ayrılma niyeti değişkenleri arasındaki ilişkilerde demografik değişkenlerin rolünün olup olmadığına yönelik etkileşim analizleri de yapılmıştır.

Şekil 1: Araştırma Modeli

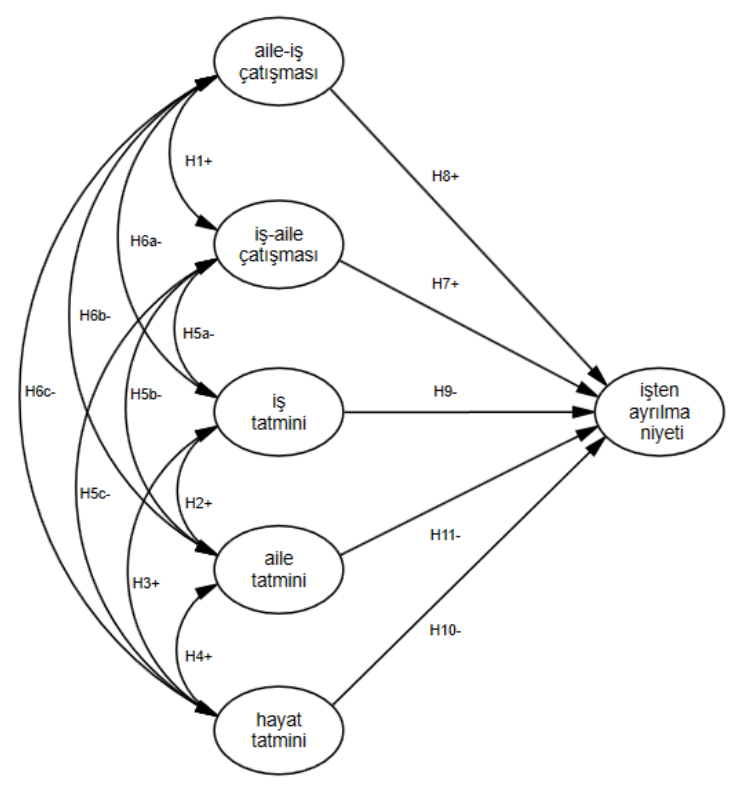




\section{Analiz Yöntemi}

Araştırmanın evrenini Mustafa Kemal Üniversitesi Sağlık Uygulama ve Araştırma Hastanesi hemşire, sağlık ve veri kayıt memurları oluşturmaktadır. Sağlık sektörünün seçilme nedeni, çalışma konusunu içeren; iş-aile çatışması, aile-iş çatışması, iş-aile-hayat tatmini gibi kavramların bu sektördeki çalışanlar açısından önem (yoğun çalışma, nöbet sistemi, insan hayatına doğrudan ilişkili mesleklerin olması vb.) taşımasından (Aktaş ve Gürkan, 2015; Tekingündüz vd., 2016) kaynaklanmaktadır. Araştırmada herhangi bir örneklem kullanılmamış olup tam sayım uygulanmıştır. Araştırmanın verileri IBM SPSS 23.0 ve AMOS 16.0 hazır istatistik programları ile analiz edilerek yorumlanmıştır. Araştırma hastanesinde Ocak 2018 yılı itibariyle hemşire, sağlık memuru ve veri kayıt memuru sayısı kadrolu ve taşeron olmak üzere toplam 695'tir. Bunlardan 315'i taşeron firma çalışanı, 380'i ise kadrolu çalışandır.

Hali hazırda çalışan tüm çalışanlara anketler dağıtılmış, toplam 568 anket çalışanlar tarafindan doldurulmuştur. 568 anket içerisinde ana kütle içerisinde yer almayan (doktor ve öğrenci) 7 anket analizden çıkarılmıştır. Ayrıca ankete verilmesi gereken cevapların büyük bir kısmı boş olan 9 anket analize alınmamıştır. Eksiksiz olarak doldurulan 552 anket istatistiki olarak değerlendirilmiştir. 237 ankette cevaplanması gereken aile tatmini ölçeğindeki ilk ifade olan evlilikten memnun olma durumunu belirten değişken katılımcılar tarafindan cevaplanmadığ 1 için analizlere dâhil edilmemiştir. Bunun nedeninin, ankete katılanların evlilikleriyle ilgili memnuniyet düzeyine cevap vermek istememeleri veya bekâr olmalarından kaynaklandığı düşünülmüştür. Araştırmada en büyük kısıt evren olmaktadır. $\mathrm{Bu}$ araştırmanın Türkiye genelinde yapılması durumunda ciddi maliyet ve zaman kaybı yaşanacağından, araştırmayı yapan kişinin yerleşim yeri olan Hatay ilinde yapılması ve bir hastanede uygulanmasına karar verilmiştir.

Anketin ilk bölümünde kontrol değişkenleri olarak alınan katılımcıların demografik özellikleri yer almıştır. İkinci bölümde ise iş tatminini ölçmede kullanılan ölçek Weiss vd.'nin (1967) geliştirdiği yirmi ifadeden oluşan Minnesota İş Doyum Ölçeğinin kısa formu yer almıştır. Ölçeğin Türkçeleştirilmiş hali Özdevecioğlu'ndan (2003) alınmış olup güvenilirliği 0,94 olarak bulmuştur. Bu çalışmada da güvenirlik 0,94 şeklinde bulunmuştur. Çalışmada aile tatminini ölçmek üzere Ji vd. (2002) tarafından geliştirilen Aile Hayat Tatmini İndeksi kullanılmıştır. Ölçek, bir bütün olarak bireyin aile yaşamından duyduğu memnuniyeti ölçmekte ve dört maddeden oluşmaktadır. Ölçeğin iç tutarlılığı araştırmacılar tarafından, 0,77 olarak belirtilmiştir. Ölçeğin Türkçeye çevrilmiş hali Coşkuner'den (2013) alınmıştır. Bu çalışmada Cronbach Alfa güvenirliliği 0,83 bulunmuştur. Katılımcıların hayattan aldıkları tatmin düzeyini ölçmek amacıyla Diener (1985) tarafından geliştirilmiş olan, beş maddeden oluşan ve Köker (1991) tarafından da Türkçeye çevrilmiş olan ve güvenirliği 0,80 olarak bulunmuş hayat tatmin ölçeği kullanılmıştır. Bu çalışmada güvenirlik 0,85 bulunmuştur. Katılımcıların iş-aile ve aile-iş çatışmasını ölçmek üzere Netemeyer vd. (1996) 
tarafından geliştirilmiş olan iki ölçek kullanılmıştır. Her biri beşer maddeden oluşan bu ölçeğin Türkçeye Efeoğlu (2006) tarafından çevrilmiş olduğu ölçek kullanılmış olup güvenilirliği iş-aile çatışması için 0,83 ve aile-iş çatışması için 0,88 olarak bulunmuştur. $\mathrm{Bu}$ çalışmada güvenirlikler ise sırasıyla 0,92 ve 0,91'dir. Katılımcıların işten ayrılma niyeti olup olmadığını ölçmek üzere Mobley vd., (1979) tarafından geliştirilen ve dört maddeden oluşan İşten Ayrılma Niyeti Ölçeği kullanılmıştır. Bu çalışmada güvenirlik 0,92 bulunmuştur.

\section{Araştırma Bulguları}

Tablo 1 incelendiğinde katılımcıların yaş ortalamasının $29,3( \pm 6,3)$ olduğu, \% 52,2' sinin evli ve \% 46,8'inin bekâr, \% 68,2'sinin bayan çalışan, \% 31,7'sinin erkek çalışan olduğu görülmektedir. Eğitim durumlarına bakıldığında; \% 17,1'inin lise ve altı, \% 34,6'sının ön lisans ve \% 48,3'ünün lisans ve üstü mezuniyete sahip olduğu görülmektedir. Ankete katılanların meslek grubuna göre değerlendirilmesinde \% 55,3'ünün hemşire, \% 7,2'sinin sağlı memuru, \% 17,5'inin veri kayıt memuru ve \% 20'sinin diğer çalışanlardan oluştuğu görülmektedir. Çalışanlara bulundukları statü açısından bakıldığında \% 40,9'nun kadrolu olduğu, \% 59,1'inin ise sözleşmeli olduğu görülmektedir. Çocuk sayısı açısından bakıldığında ortalama 0,63( $\pm 0,98)$, toplam çalışma sürelerinin ortalamasının ise $77,4( \pm 60,2)$ olduğu tespit edilmiştir.

Tablo 1: Çalışanların Demografik Özellikleri ile İlgili Veriler

\begin{tabular}{rrrr}
\hline Değişken & Kategori & Frekans & Yüzde (\%) \\
\hline Cinsiyet & Kadın & 377 & 68,2 \\
& Erkek & 175 & 31,7 \\
\hline Medeni Durum & Evli & 283 & 52,2 \\
& Bekâr & 259 & 46,8 \\
\hline Eğitim Durumu & Lise ve altı & 88 & 17,1 \\
& Ön lisans & 178 & 34,6 \\
& Lisans ve üstü & 249 & 48,3 \\
\hline Meslek & Hemşire & 285 & 55,3 \\
& Sağlık memuru & 37 & 7,2 \\
& Veri kayıt memuru & 90 & 17,5 \\
\hline Bulunulan Statü & Diğer & 103 & 20,0 \\
\hline Yaş ortalaması (standart sapma) & Kadrolu & 193 & 40,9 \\
Çocuk sayısı ortalaması (standart sapma) & 279 & 59,1 \\
Toplam çalışma süresi ortalaması (standart sapma) & $77,41(60,164)$ ay & Min. 1; Maks. 480 ay \\
\hline
\end{tabular}

\subsection{Yapı Geçerliliği ve Güvenirliliği}

Ölçeklerdeki ifadelerin bir arada toplanıp toplanmadığına ve teorik modellerine uygun şekilde gruplanıp gruplanmadığına yönelik yapı geçerliliği için Açımlayıcı ve Doğrulayıcı Faktör Analizleri (AFA ve DFA) yapılmıştır. Öncelikle tüm ifadeler tek bir havuzda AFA'ya tabi tutulmuştur. Örneklem yeterliliğine yönelik olarak Kaiser-Meyer-Olkin (KMO) 0,92 ve Barlett küresellik testinde maddeler yaklaşık 
$\chi_{\mathrm{df}=861}^{2} 13157,725 ; \mathrm{p} \leq 0,001$ düzeyinde anlamlı çıktığından faktör analizinin yapılabileceğine karar verilmiştir. Açımlayıcı yöntem olarak Temel Bileşenler Analizi ve rotasyon yöntemi olarak Kaiser normalleştirmeli Varimax kullanılmıştır. AFA sonucunda 0,40 faktör yükü üzerindeki 42 ifade $\%$ 70,748 açımlama gücü ile sekiz faktörde toplanmıştır. İş tatmini ölçeği haricinde diğer tüm ölçeklerin ifadeleri modellerine uygun şekilde toplanmıştır (faktörlerin yükleri iş-aile çatışması (WFC) için 10,112; aile-iş çatışması (FWC) 9,436; hayat tatmini (LS) 8,196; işten ayrılma niyeti (JIL) 8,048; aile tatmini (FSS) 5,554). İş tatmini ölçeğindeki ifadeler ise üç farklı faktörde toplanmıştır (MJS 1 için 5 ifadenin toplam faktör yükü 5,257; MJS 2 için 5 ifade 9,997 ve MJS 3 için 10 ifade 14,147).

Bu faktörlerin yapı geçerliğini doğrulamak için AFA'da çıkan sonuç üzerinden yapılan DFA'da iyi uyum istatistikleri üretmemiştir. MJS 2'de bir ifade ve MJS 3'te üç ifadenin farklı faktörlerle yüksek ilişkili olduğu görüldüğünden bunlar silinmiş ve ayrıca programın önerdiği hata terimleri arasındaki kovaryanslar çizilmiștir. Böylece birinci düzey model kabul edilebilir iyi uyum istatistikleri üretmiştir

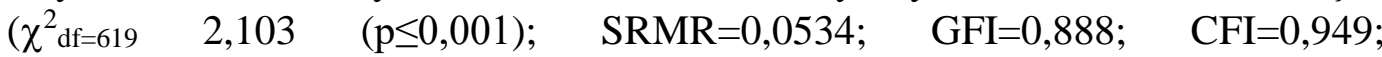
RMSEA=0,045). Aynı sonuçlar üzerinden üç alt boyutlu iş tatmininin bir faktörde toplanıp toplanmadığına yönelik yapılan ikinci düzey DFA da kabul edilebilir iyi uyum istatistikleri üretmiştir $\left(\chi_{\mathrm{df}=629}^{2} 2,161(\mathrm{p} \leq 0,001)\right.$; $\mathrm{SRMR}=0,0571 ; \mathrm{GFI}=0,881$; $\mathrm{CFI}=0,946$; RMSEA=0,046). İkinci düzey DFA sonucunda ortaya çıkan faktör yükleri için yapılan geçerlilik ve güvenirliği ile ilgili sonuçlar kabul edilebilir düzeydedir (MJS için $\mathrm{AVE}=0,87$; $\mathrm{CR}=0,95$ ve $\mathrm{AlfA}=0,92 ; \mathrm{MJS} 1$ için $\mathrm{AVE}=0,46$; $\mathrm{CR}=0,81$ ve $\mathrm{Alf} A=0,87 ; \mathrm{MJS} 2$ için $\mathrm{AVE}=0,51 ; \mathrm{CR}=0,80$ ve $\mathrm{Alf} A=0,82 ; \mathrm{MJS} 3$ için $\mathrm{AVE}=0,45 ; \quad \mathrm{CR}=0,85$ ve $\mathrm{Alf} A=0,86 ;$ WFC için $\mathrm{AVE}=0,69 ; \mathrm{CR}=0,92$ ve $\mathrm{AlfA}=0,92 ; \mathrm{FWC}$ için $\mathrm{AVE}=0,68 ; \mathrm{CR}=0,91$ ve $\mathrm{AlfA}=0,91 ; \mathrm{LS}$ için $\mathrm{AVE}=0,52$; $\mathrm{CR}=0,84$ ve $\mathrm{Alf} A=0,85 ; \mathrm{JIL}$ için $\mathrm{AVE}=0,75 ; \mathrm{CR}=0,92$ ve $\mathrm{AlfA}=0,92 ; \mathrm{FSS}$ için $\mathrm{AVE}=0,68 ; \mathrm{CR}=86$ ve $\mathrm{Alf} A=0,82$ ).

Tablo 2: Korelasyon ve Tanımlayıcı İstatistikler

\begin{tabular}{|c|c|c|c|c|c|c|c|c|c|c|c|c|c|c|}
\hline & Çocuk & Yas & Tecrübe & MJS & |MJS_1 & MJS_2 & MJS_3 & WFC & FWC & LS & JIL & Ort. & S.S. & $\mathrm{N}$ \\
\hline Çocuk & & & & & & & & & & & & 0,63 & \begin{tabular}{|l|}
0,98 \\
\end{tabular} & 553 \\
\hline Yas & $\mathbf{0 , 5 9} 9^{* *}$ & & & & & & & & & & & 29,36 & 6,26 & 530 \\
\hline Tecrübe & $\mathbf{0 , 3 8}{ }^{* * *}$ & $0,72^{* * *}$ & & & & & & & & & & 77,41 & 60,16 & 524 \\
\hline MJS & $0,13^{\text {*** }}$ & 0,05 & 0,04 & & & & & & & & & 3,08 & 0,79 & 553 \\
\hline MJS_1 & 0,16 *** & 0,08 & $0,09^{*}$ & $\mathbf{0 , 9 4 ^ { * * }}$ & & & & & & & & 3,37 & 0,83 & 553 \\
\hline MJS_2 & $\mathbf{0 , 0 9} *$ & 0,01 & 0,03 & $\mathbf{0 , 8 4 ^ { * * }}$ & $0,66^{* *}$ & & & & & & & 2,69 & 0,93 & 553 \\
\hline MJS_3 & 0,08 & 0,01 & 0,02 & $\mathbf{0 , 8 8 ^ { * * }}$ & $\mathbf{0 , 7 3}{ }^{* *}$ & $0,66^{* * *}$ & & & & & & 2,90 & 0,92 & 553 \\
\hline WFC & $-1,11 *$ & 0,09 & $-0,09$ & $-0,34^{* *}$ & $-0,24 *$ & $-0,32$ ** & $\mid-0,39^{\text {*** }}$ & & & & & 3,19 & 1,00 & 553 \\
\hline FWC & $0,12^{* * *}$ & $-1,11^{*}$ & 0,08 & $-0,23^{* * *}$ & $\left|-0,25^{*} *\right|$ & $-0,11^{*}$ & $\left|-0,22^{\text {*** }}\right|$ & $0, \mathbf{4 3}^{\text {*** }}$ & & & & 2,46 & 0,99 & 553 \\
\hline LS & 0,07 & 0,03 & 0,02 & $\mathbf{0 , 3 2}{ }^{* *}$ & $\mathbf{0 , 2 8}{ }^{* * *}$ & $\mathbf{0 , 3 3}{ }^{* *}$ & $\mathbf{0 , 2 5}{ }^{\text {** }}$ & $-0,16$ *** & $0,10^{*}$ & & & 2,83 & 0,87 & 553 \\
\hline JIL & $0,12^{\text {**** }}$ & $1,10^{*}$ & 0,08 & $-0,51^{\text {*** }}$ & $-0,45^{* *}$ & $-0,44$ & $-0,48^{* * *}$ & $\mathbf{0 , 5 0}$ & $0,38^{* *}$ & $-0,15^{* *}$ & & 2,86 & 1,14 & 552 \\
\hline FSS & $0,12^{* * *}$ & 0,10 & 0,09 & $\mathbf{0 , 3 1} 1^{* *}$ & $\mathbf{0 , 2 3}{ }^{* *}$ & $0,32^{* *}$ & $0,30^{* *}$ & $-0,25^{* *}$ & $-0,22 * * \mid$ & $0,28^{* * *}$ & $-0,16$ *** & 3,28 & 0,94 & 524 \\
\hline
\end{tabular}

Not: MJS: Genel iş tatmini; MJS_1: İçsel tatmin/kendini geliştirme; MJS_2: Dışsal tatmin boyutu; MJS_3: İçsel tatmin/işin niteliği boyutu; WFC: İş-aile çatışması; FWC: Aile-iş çatışması; LS: Hayat tatmini; JIL: İşten ayrılma niyeti; FSS: Aile tatmini. ${ }^{*} \mathrm{p}<0,05 ;{ }^{* *} \mathrm{p}<0,01$ düzeyinde anlamlıdır. 


\subsection{Model Analizi}

Amaçlanan modelin testine yönelik oluşturulan yapılan eşitlik modeli kabul edilebilir sonuçlar vermesine $\left(\chi_{\mathrm{df}=669}^{2,180}(\mathrm{p} \leq 0,001)\right.$; $\mathrm{SRMR}=0,064$; GFI=0,877; $\mathrm{CFI}=0,942$; RMSEA=0,046) karşın, anlamsız yol ve kovaryanslar kontrol değişkenlerinden başlanarak silinmiştir. Kontrol değişkenlerinden yalnızca eğitimin işten ayrılmaya olan etkisi anlamlı $(\beta=0,157 ; \mathrm{p} \leq 0,001)$ çıkmıştır.

Yapısal eşitlik modelinin analiz sonuçları itibari ile hipotezlerin üç tanesi hariç diğerleri doğrulanmıştır (Tablo 3). İş tatmini (MJS) işten ayrılma niyetini (JIL) negatif yönde etkilerken $(\beta=-0,403 ; \mathrm{p} \leq 0,001)$, iş-aile çatışması (WFC) ve aile-iş çatışması (FWC) pozitif yönde (sırasıly $\beta=0,273 ; \quad \beta=0,200 ; \quad \mathrm{p} \leq 0,001$ ) etkilemektedir $\left(\mathrm{H}_{7} ; \mathrm{H}_{8}\right.$ ve $\mathrm{H}_{9}$ kabul). İşten ayrılmaya olan tüm bu etkilerin gücü $R^{2}=0,45^{\prime}$ tir.

Tablo 2' de görüldüğü üzere yapılan korelasyon analizine göre değişkenler arasında zayıf ve orta derecede anlamlı ilişkiler bulunmuştur. Modeldeki, ilișkilere bakıldığında (Tablo 3), iş-aile çatışması (WFC) ile hayat tatmini (LS), aile tatmini (FSS) ve iş tatmini (MJS) ile negatif yönde ilişkili (sırasılyla cor $=-0,201 ;$ cor $=-0,241$ ve cor $=-0,390 ; \mathrm{p} \leq 0,001$ ); aile-iş çatışması (FWC) aile tatmini (FSS) ve iş tatmini (MJS) ile negatif ilişkili (sırasıyla cor $=-0,296$ ve cor $=-0,278 ; \mathrm{p} \leq 0,001$ ) bulunmuştur $\left(\mathrm{H}_{5 \mathrm{c}} ; \mathrm{H}_{5 \mathrm{~b}} ; \mathrm{H}_{5 \mathrm{a}} ; \mathrm{H}_{6 \mathrm{a}}\right.$ ve $\left.\mathrm{H}_{6 \mathrm{~b}} \mathrm{kabul}\right)$. İş tatmini (MJS) aile tatmini (FSS) ve hayat tatminiyle (LS) (sirasiyla cor $=0,293$ ve cor $=0,404 ; \mathrm{p} \leq 0,001$ ); aile tatmini (FSS) hayat tatminiyle (LS) $($ cor $=0,278 ; \mathrm{p} \leq 0,001)$ ve son olarak iş-aile çatışması (WFC) aile-iş çatışmasıyla $(\mathrm{FWC})($ cor $=0,457 ; \mathrm{p} \leq 0,001)$ pozitif yönde ilişkili çıkmıştır $\left(\mathrm{H}_{2} ; \mathrm{H}_{3} ; \mathrm{H}_{4}\right.$ ve $\mathrm{H}_{1}$ kabul).

Tablo 3: Yapısal Eşitlik Modeli İstatistikleri

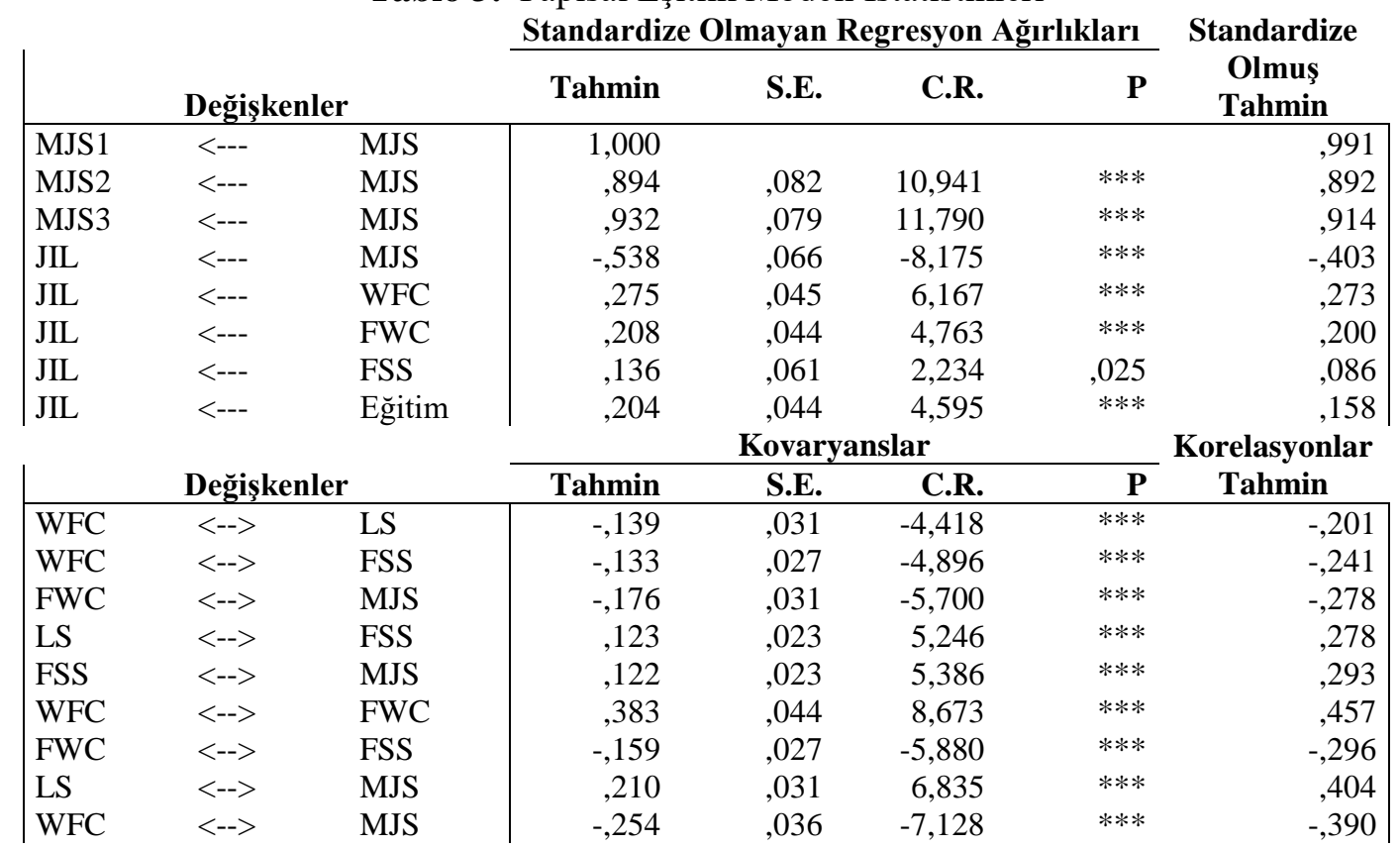


Amaçlanan modelde belirtilen hayat tatmininin (LS) işten ayrılma niyetine (JIL) olan etkisi istatistiki olarak anlamsız $(\beta=0,015 ; \mathrm{p}=0,732)$ çıkmış $\left(\mathrm{H}_{10}\right.$ ret $)$, hayat tatmini (LS) ile aile-iş çatışması ilişkisi (FWC) ise anlamsız (cor $=0,078 ; \mathrm{p}=0,105)$ olmuştur $\left(\mathrm{H}_{6 c}\right.$ ret). Ayrıca aile tatmini (FSS) de daha düşük bir anlamlılık düzeyinde olsa da işten ayrılma niyetini (JIL) amaçlanan hipotezin tersine pozitif yönde $(\beta=0,086 ; \mathrm{p}=0,025)$ etkilediği çıkmıştır $\left(\mathrm{H}_{11}\right.$ ret $)$.

\subsection{Etkileşim Analizleri}

Ana değişkenler arasındaki ilişkilerde demografik değişken ve ana değişkenlerin rolünün olup olmadığına yönelik etkileşim analizleri yapılmıştır. Bunun için analizlere konu olan aralıklı olarak ölçeklendirilmiş değişkenleri kategorik hale getirmek için ortalamalarına göre kesme noktası belirlenmiş ve kesme noktasının altındaki değerler 'düşük', üstündekilere ise 'yükssek' şeklinde kategorilendirilmiştir. Nominal şekilde ölçeklendirilmiş değişkenlerde herhangi bir değişiklik yapılmamıştır. Analizlerde Soper'ın (2019) 'interaction' programından yararlanılmıştır.

Grafik 1: Etkileşim Grafikleri
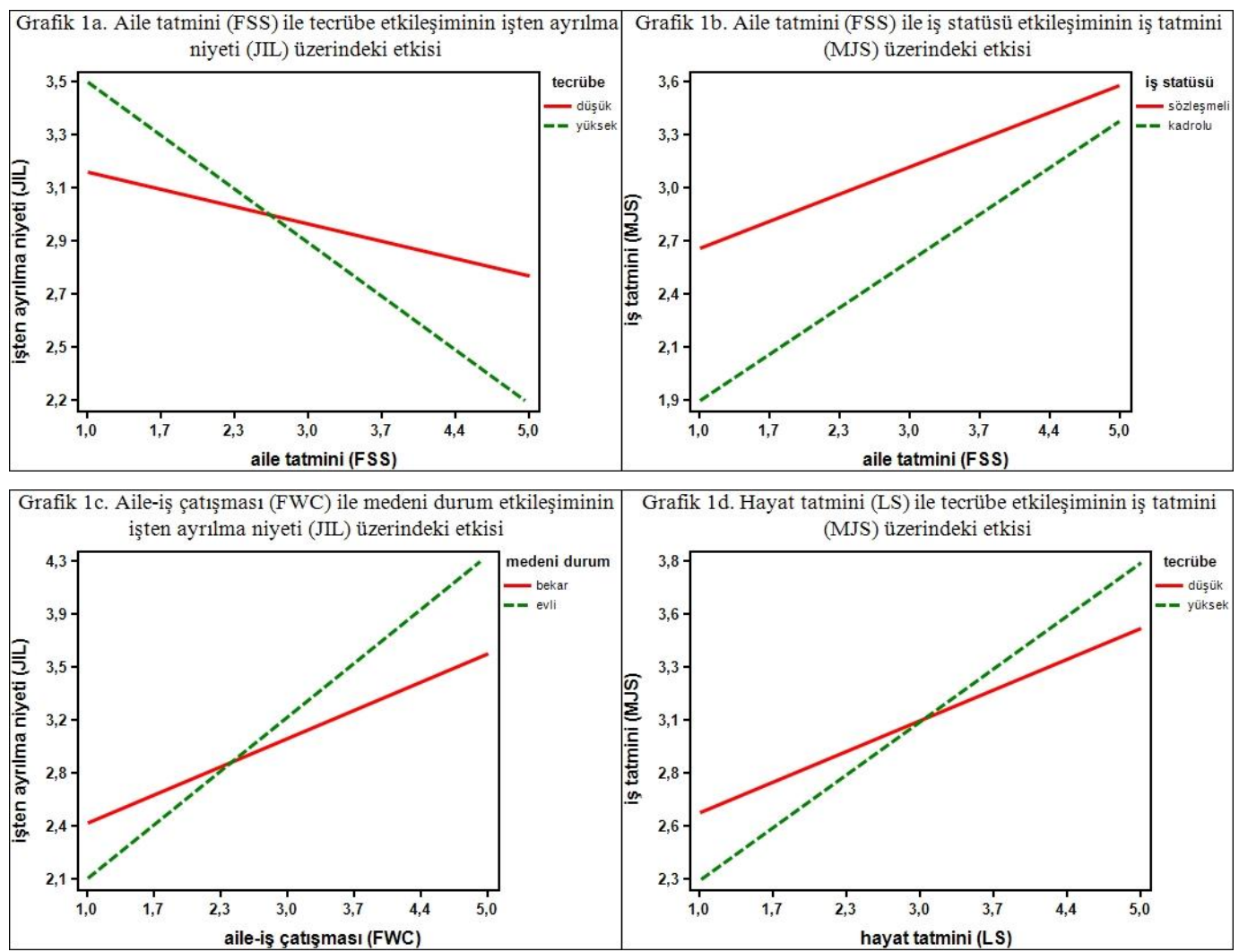

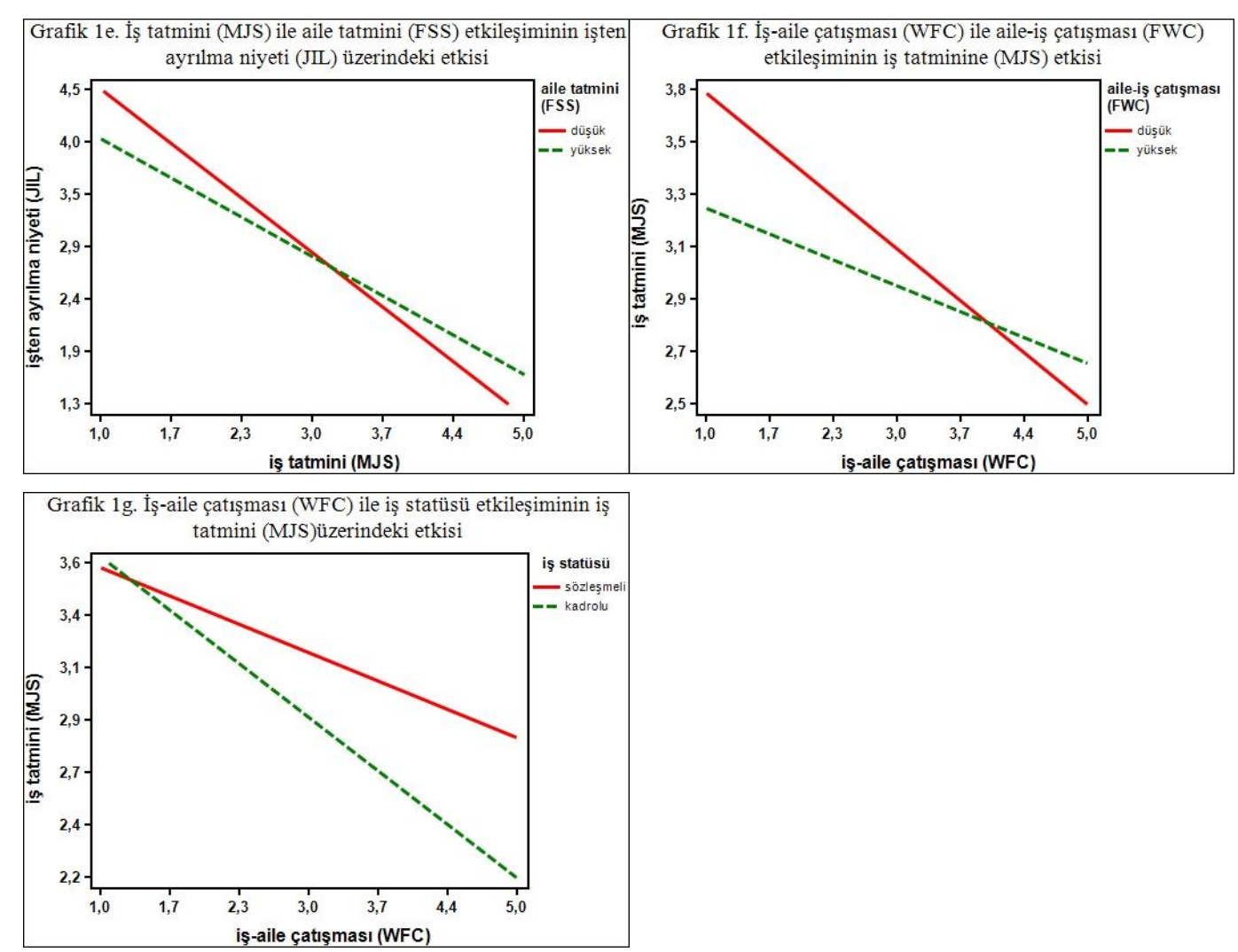

Aile tatmini ile tecrübe etkileşiminin işten ayrılma niyeti üzerine etkisi olduğu bulunmuştur (Tablo 4). Tecrübesi daha yüksek olanlar düşük olanlara göre aile tatminin işten ayrılma niyetini daha yüksek bir şekilde olumsuz etkilemektedir (Grafik 1a). Aile tatmini ile iş statüsü etkileşiminin iş tatmini üzerindeki etkisinde sözleşmeli çalışanın kadrolu çalışana göre tatmini düzeyi daha yüksektir (Grafik 1b). Aile-iş çatışması ile medeni durum etkileşiminin işten ayrılma niyeti üzerine etkisinde, evli çalışanlar aile-iş çatışması yaşadıkça işten ayrılma konusunda daha duyarlı olmaktadırlar (Grafik 1c). Hayat tatmininin iş tatminine etkisinde tecrübesi düşük çalışanlar daha duyarlıdırlar (Grafik 1d). İş tatmini ile aile tatmini etkileşiminin işten ayrılma niyetine etkisinde aile tatmini düşük olanlar daha duyarlıdırlar (Grafik 1e). İş-aile çatışması ile aile-iş çatışması etkileşiminde aile-iş çatışması düşük olanların iş tatmini daha yüksektir. İş-aile çatışması ile iş statüsü etkileşiminin iş tatmini üzerindeki etkisinde kadrolu çalışanlar daha duyarlı olmaktadırlar. Yani kadrolularda iş-aile çatışması iş tatminini daha yüksek oranda etkilemektedir (Grafik 1g). Luk ve Shaffer (2005), çalışmalarında aile-iş çatışması ile ailesel talepler ve aileye bağlılık arasındaki ilişkinin pozitif yönlü, patronun desteği ve eş desteği arasındaki ilişkinin ise negatif yönlü olduğunu tespit etmişlerdir. Buna göre, çalışanlarda aile-iş çatışması arttıkça ailenin isteklerinin ve aileye bağlılık duygusunun arttığını, çalışanların yöneticilerinden aldıkları destek ve takdir arttıkça aileden gelen desteğin azaldığı söylenebilir. 
Özden AKIN, Hüseyin KARAKULAK

Tablo 4: Etkileşim Analizi İstatistikleri

\begin{tabular}{|c|c|c|c|c|c|}
\hline Model & Değişkenler & $B$ & Std. Hata & $t$ & Model Özeti \\
\hline \multirow{4}{*}{ FSSxEXP $\rightarrow$ JIL } & Sabit & 3,25 & 0,23 & $14,28 * * *$ & $R=0,18$ \\
\hline & FSS & $-0,10$ & 0,07 & $-1,53$ & $R^{2}=0,032$ \\
\hline & Aylak değişken 1 & 0,57 & 0,36 & 1,56 & \multirow{2}{*}{$\begin{array}{l}\text { Düzenlenmiş } R^{2}=0,27 \\
F=6,05 * * * \\
\text { Etki büyüklüğü }\left(f^{2}\right)=0,03\end{array}$} \\
\hline & Etkileşim terimi 1 & $-0,21$ & 0,11 & $-1,99 *$ & \\
\hline \multirow{4}{*}{ FSSxSTATU $\rightarrow$ MJS } & Sabit & 1,47 & 0,19 & $7,88 * * *$ & \multirow{4}{*}{$\begin{array}{l}R=0,43 \\
R^{2}=0,19 \\
\text { Düzenlenmiş } R^{2}=0,18 \\
F=42,18 * * * \\
\text { Etki büyüklüğü }\left(f^{2}\right)=0,23\end{array}$} \\
\hline & FSSş & 0,38 & 0,05 & 7,06 *** & \\
\hline & Aylak değişken 1 & 0,99 & 0,23 & $4,21 * * *$ & \\
\hline & Etkileşim terimi 1 & $-0,16$ & 0,07 & $-2,30^{*}$ & \\
\hline \multirow{4}{*}{ FWCxMARITAL $\rightarrow$ JIL } & Sabit & 1,49 & 0,16 & $9,15 * * *$ & \multirow{4}{*}{$\begin{array}{l}R=0,39 \\
R^{2}=0,15 \\
\text { Düzenlenmiş } R^{2}=0,15 \\
F=32,51 * * * \\
\text { Etki büyüklüğü }\left(f^{2}\right)=0,18\end{array}$} \\
\hline & FWC & 0,56 & 0,06 & $8,74 * * *$ & \\
\hline & Aylak değişken 1 & 0,66 & 0,24 & $2,72 * *$ & \\
\hline & Etkileşim terimi 1 & $-0,27$ & 0,09 & $-2,93 * *$ & \\
\hline \multirow{4}{*}{ LSxEXP $\rightarrow$ MJS } & Sabit & 2,43 & 0,15 & $16,66^{* * *}$ & \multirow{4}{*}{$\begin{array}{l}R=0,33 \\
R^{2}=0,11 \\
\text { Düzenlenmiş } R^{2}=0,10 \\
F=22,38^{* * *} \\
\text { Etki büyüklüğü }\left(f^{2}\right)=0,12\end{array}$} \\
\hline & LS & 0,22 & 0,05 & $4,38 * * *$ & \\
\hline & Aylak değişken & $-0,48$ & 0,22 & $-2,20 *$ & \\
\hline & Etkileşim terimi 1 & 0,16 & 0,07 & $2,14 *$ & \\
\hline \multirow{4}{*}{ MJSxFSS $\rightarrow$ JIL } & Sabit & 5,36 & 0,22 & $23,92 * * *$ & \multirow{4}{*}{$\begin{array}{l}R=0,50 \\
R^{2}=0,26 \\
\text { Düzenlenmiş } R^{2}=0,25 \\
F=61,89 * * * \\
\text { Etki büyüklüğü }\left(f^{2}\right)=0,34\end{array}$} \\
\hline & MJS & $-0,82$ & 0,08 & $-10,87 * * *$ & \\
\hline & Aylak değişken & $-0,74$ & 0,34 & $-2,15^{*}$ & \\
\hline & Etkileşim terimi & 0,23 & 0,11 & $2,09 *$ & \\
\hline \multirow{4}{*}{ WFCxFWC $\rightarrow$ MJS } & Sabit & 4,04 & 0,12 & $32,96 * * *$ & \multirow{4}{*}{$\begin{array}{l}R^{2}=0,14 \\
\text { Düzenlenmiş } R^{2}=0,13 \\
F=28,47 * * * \\
\text { Etki büyüklüğü }\left(f^{2}\right)=0,16\end{array}$} \\
\hline & WFC & $-0,31$ & 0,04 & $-7,85 * * *$ & \\
\hline & Aylak değişken & $-0,62$ & 0,35 & $-2,53 *$ & \\
\hline & Etkileşim terimi & 0,16 & 0,07 & $2,22 *$ & \\
\hline \multirow{4}{*}{ WFCxSTATU $\rightarrow$ MJS } & Sabit & 3,96 & 0,19 & $20,77 * * *$ & \multirow{4}{*}{$\begin{array}{l}R=0,42 \\
R^{2}=0,17 \\
\text { Düzenlenmiş } R^{2}=0,17 \\
F=38,36^{* * *} \\
\text { Etki büyüklüğ̈̈ }\left(f^{2}\right)=0,21\end{array}$} \\
\hline & MJS & $-0,35$ & 0,05 & $-6,63 * * *$ & \\
\hline & Aylak değişken & $-0,21$ & 0,23 & $-0,94$ & \\
\hline & Etkileşim terimi & 0,17 & 0,07 & $2,53 *$ & \\
\hline
\end{tabular}

Not: $* * * \mathrm{p} \leq 0,001 ; * * * \mathrm{p} \leq 0,01 ; * * * \mathrm{p} \leq 0,05$;

\section{Tartışma ve Sonuç}

Araştırma bulgularına göre çalışanlarda iş tatmini arttıkça iş-aile çatışması azalmaktadır. Bu sonuç çalışanın işini yaparken duyduğu mutluluk arttıkça, iş-aile çatışmasını daha az yaşadığ 1 şeklinde yorumlanabilir. Qu ve Zhao (2012) iş-aile çatışmasının farklı durum ve koşullarda iş tatmini ve hayat tatmini üzerinde etkisini araştırmıştır. Bu çalışma ile paralel çıkan sonuçlar, iş ve aile arasında daha az çatışma yaşayan çalışanların günlük yaşamdan işyerine olumlu yönler taşıma eğiliminde olduklarını göstermektedir. Bu sonuçlara göre işinden memnun ve mutlu olmayan çalışanların aile hayatlarında da mutlu olmadıkları ve iş hayatı aile hayatındaki oynaması gereken rolleri engellendiğinde ve kısıtlandığında uyumsuzlukların ve tatminsizliklerin doğabileceği görülmektedir. 
Çalışmada çalışanların işlerinden duydukları tatmin arttıkça, aile-iş arasındaki yaşanan çatışmaların azaldığı sonucuna ulaşılmıştır. Aile-iş çatışması, çalışanların aile ile ilgili yaşadıkları sorunların işlerini etkilemesinden kaynaklanmaktadır. Buna göre çalışanların aile sorumluluklarını yerine getirememesi, iş ile ilgili performansını da gerçekleştirememesine neden olmaktadır. Çalışanın evli ya da dul olması, okul öncesi ve okul sonrası çocuk sayısı, eşin çalışıyor ya da çalışmıyor olması ve aile yapısı aile-iş çatışmasını ortaya çıkarabilecek nedenler olabilmektedir (Atabay, 2012). Araştırmanın bir diğer bulgusu ise, iş tatmininin hayat tatmini üzerindeki pozitif ve anlamlı ilişkisidir. İş tatmini içsel ve dışsal iş tatmini olarak ikiye ayrıldığında iş tatmini ve hayat tatmini arasındaki ilişkinin gücünü belirlemek daha anlamlı olacaktır. Bu çalışmada iş tatmini içsel tatmin/kendini geliştirme, dışsal tatmin ve içsel tatmin/işin niteliği olmak üzere üç boyuta ayrılmıştır. Birinci ve üçüncü boyut içsel tatmini ikinci boyut ise dişsal tatmini temsil etmektedir. Bu boyutların hayat tatmini ve aile tatmini ile olan ilişki durumunda dişsal tatmin boyutunun ilişki durumunun daha yüksek olduğu görülmektedir. D1şsal iş tatmini olarak değerlendirilebilecek iş ile ilgili çıktılar alınan ücret ve prestij olarak değerlendirilirse bu çıktıların hayat tatminine olan katkısı da yüksek olacaktır. Ayrıca iş tatmini boyutlarından olan dışsal tatmin boyutu aile-iş çatışmasıyla daha yüksek ilişkili çıkmıştır.

Araştırmada iş-aile çatışması ve hayat tatmini arasında negatif ve anlamlı sonuç bulunmuştur. Ancak aile-iş çatışması ile hayat tatmini arasında pozitif yönde ve zayıf bir ilişki bulunmuştur. Siegel vd. (2005) çalışanların güçlü derecede iş-aile ve aile-iş çatışması yaşadıklarında işe olan katkısının ve genel olarak da yaşam kalitesinin ya pozitif ya da negatif yönde etki ettiğini söylemektedir. Ayrıca, bireyler iş ve aile dengesini sağlamada yeterli yeteneğe sahip olmadığında, öncelikle aile hayatlarını düzenleme eğilimli oldukları görülmektedir (Frone vd., 1992). Özdevecioğlu ve Doruk (2009) yaptıkları araştırmada, çalışanların iş-aile ve aile-iş çatışmalarının hayat tatminlerini olumsuz etkilediğini göstermiş ve aralarındaki ilişkiyi negatif yönlü bulmuşlardır. Ancak aile-iş çatışmasının iş tatmini üzerinde anlamlı bir etkide bulunmadığı sonucuna ulaşmışlardır. $\mathrm{Bu}$ çalışmada da Özdevecioğlu ve Doruk'un ulaştığı sonuçlara ulaşılmıştır.

Çalışmada iş, aile, hayat tatmini, iş-aile, aile-iş çatışması ve işten ayrılma niyeti değişkenler arası ilişkilerde medeni durum, tecrübe, iş statüsü gibi demografik değişkenlerin rolü olduğu görülmüştür. Tecrübeli ve evli çalışanların işten ayrılma niyetine daha duyarlı oldukları, sözleşmeli çalışanların iş tatmininin daha yüksek olduğu, kadrolu çalışanların iş-aile çatışması yaşadıklarında iş tatminine daha olumsuz etkide bulunduğu görülmüştür. Karatepe (2008), hastane çalışanlarının iş ve hayat koşullarının zor ve hassas olması sebebiyle, iş ve aile arasındaki dengeyi kurmakta zorluklar yaşadıklarını ifade etmiştir. Akdağ vd. (2015) çalışmalarında örgüt içerisinde aşırı rol yükü olan çalışanların işten ayrılma niyetinin yüksek olduğu sonucuna ulaşmışlardır. Bu çalışmalara göre işten ayrılma niyetine etki eden kişisel ve örgütsel faktörlerin çalışan için önemli bir karar verici olduğu görülmektedir. 
$\mathrm{Bu}$ çalışmada aile tatmini arttıkça, işten ayrılma niyetinin azaldı̆̆ ulaşılmıştır. Yine çalışmada ulaşılan aile tatmini arttıkça, iş tatmininin ve hayat tatmininin arttığ 1 sonucu, çalışanların aile tatmininin artması işten duydukları tatminin ve hayattan duydukları tatminin de artmasına neden olduğunu göstermektedir (Diener ve Lucas, 1999). İnsanlar aileleriyle mutlu ve huzurlu olduklarında bunu işlerine de yansıtmaktadır (Kiecolt, 2003).

Bu çalışma Hatay ilinde bir Araştırma Hastanesinde yapılması, kapsam açısından daha geniş bir sahada yapılmadığından dar bir kitleyi kapsamaktadır. Bu anlamda çalışma sahasının diğer sağlık sektörü kurumları ve diğer sektörler dâhil edilerek daha genel bir evrende yapılması önerilmektedir. Çalışmada kullanılan kavramlara ek olarak örgütsel bağlılık, iş yaşamı kalitesi, çalışanların iş yükü durumu gibi kavramlar da dâhil edilerek daha geniş kapsamlı çalışmalar yapılması önerilebilir.

\section{Kaynakça}

Adams, G.A., King, L.A., \& King, D.W. (1996). Relationships of job and family involvement, family social support, and work-family conflict with job and life satisfaction. Journal of Applied Psychology, 8(4), 411-420.

Akbolat, M., Yılmazer, A., \& Tutar, H. (2014). Konaklama işletmeleri çalışanlarının algıladıkları mobbingin iş tatmini ve işten ayrılma niyetine etkisi. Manas Sosyal Araştırmalar Dergisi, 3(3), 1-17.

Aktaş, H., \& Gürkan, G.Ç. (2015). İş-aile ve aile-iş çatışması ile bireysel performans etkileşiminde mesleki bağlılığın aracı rolü: Hemşireler üzerinde bir araştırma. Doğuş Üniversitesi Dergisi, 16(2), 139-154.

Aslan, Ş. (2004). Hastanelerde örgütsel çatışma: Teori ve örnek bir uygulama. Selçuk Üniversitesi Sosyal Bilimler Enstitüsü Dergisi, 11, 599-617.

Atabay, E.S. (2012). Işs-aile çatışması ile iş tatmini ilişkisi: Banka çalışanları üzerinde bir uygulama. Yüksek Lisans Tezi, Atatürk Üniversitesi Sosyal Bilimler Enstitüsü, Erzurum.

Aydemir, P., \& Erdoğan, E. (2013). İş görenlerin ücret tatmini, iş tatmini ve performans algısı. Катu-Işs Iş Hukuku ve İktisat Dergisi, 13(2), 127-153.

Bartlett, K.R. (2001). The relationship between training and organizational commitment in the health care field. Human Resource Development Quarterly, 12(4), 335-352.

Brief A. P., Butcher A.H., George J.M., \& Link K.E (1993). Integrating bottom-up and top-down theories of subjective well-being: The case of health. Journal of Personality and Social Psychology, 64(4), 646-53.

Büyükyılmaz, O., \& Akyüz, S. (2015). Safranbolu'daki otel ve konak çalışanlarının algıladığ 1 iş-aile yaşam çatışmasının iş tatmini üzerindeki etkisi. Akademik Bakış Dergisi, 52, 265-284. 
Cazan, A. M., Truta, C. \& Mariela, P. I. (2019). The work-life conflict and satisfaction with life: Correlates and the mediating role of the work-family conflict. Romanian Journal of Applied Psychology, 21(1), 3-10.

Cinamon, R.G. (2006). Anticipated work-family conflict: effects of gender, self efficiancy and family background. The Career Development Quarterly, March, $54,202-215$.

Çekmecelioğlu, G.H. (2005). Örgüt ikliminin iş tatmini ve işten ayrılma niyeti üzerindeki etkisi: Bir araştırma. C.Ü. İktisadi ve İdari Bilimler Dergisi, 6(2), $23-39$.

Cohen, A. (1997). Nonwork influences on withdrawal cognitions: An empirical examination of an overlooked issue. Human Relations, 50(12), 1511-1536.

Coşkuner, S. (2013). Akademisyenlerin iş ve aile karakteristiklerinin evlilik, aile ve yaşam tatmini ile ilişkisi: Işs ve aile çatışmasının aracı rolü. Hacettepe Üniversitesi Sosyal Bilimler Enstitüsü, Aile ve Tüketici Bilimleri, Yayınlanmamış Doktora Tezi, Ankara.

Cranny, C.J., Smith, P.C., \& Stone, E.F. (1992). Job satisfaction: How people feel about their job and how it affects their performance. New York: Lexington Boks.

Çarıkçı, İ.H., \& Çelikkol, Ö. (2009). İş-aile çatışmasının örgütsel bağlılık ve işten ayrılma niyetine etkisi. Süleyman Demirel Üniversitesi Sosyal Bilimler Enstitüsü Dergisi, 1(9),153-170.

Dockery, A.M. (2004). Happiness, life satisfaction and the role of work: Evidence from two Australian surveys. Unpublished Mimeo, 1-20.

Diener, E., Emmons, R.A., Larsen, R.J., \& Griffin, S. (1985). The satisfaction with life scale. Journal of Personality Assessment, 49(1), 71-75.

Diener, E., \& Lucas, R.E. (1999). Subjective well-being, three decades of progress. Psychological Bulletin, 125(2), 276-303.

Edwards, J.R., \& Rothbard, N.P. (2000). Mechanisms linking work and family: Clarifying the relationship between work and family constructs. Academy of Management Review, 25, 178-199.

Efeoğlu, İ.E. (2006). İş-aile yaşam çatışmasının iş stresi, iş doyumu ve örgütsel bağlllık üzerindeki etkileri. Yayınlanmamış Doktora Tezi, Çukurova Üniversitesi Sosyal Bilimler Enstitüsü, Adana.

Ford, M.T., Heinen, B.A.,\& Langkamer, K.L. (2007). Work and family satisfaction and conflict: A meta analysis of cross-domain relations. Journal of Applied Psychology, 92(1), 57-80. 
Frone, M.R., Russell, M., \& Cooper M.L. (1992). Antecedents and outcomes of work family Conflict: Testing a model of the work-family interface. Journal of Applied Psychology, 77(1), 65-78.

Greenhaus J.H, \& Beutell N.J. (1985). Sources of conflict between work and family roles. The Academy of Management Review, 10, 76-88.

Hasyurt, R. (2017). İş-aile çatışması ve işten ayrılma niyeti ilişkisi: İstanbul'da enerji sektöründe Türk ve Çinli yönetici çallştıran bir işletme örneği. Yüksek Lisans Tezi, Gazi Üniversitesi Sosyal Bilimler Enstitüsü, Ankara.

Heller, D., Judge, T.A, \& Waston, D. (2002). The confounding role of personality and trait affectivity in the relationship between job and life satisfaction. Journal of Organizational Heller Behavior, 23, 815-835.

Heller, D., Watson, D., \& Hies, R. (2004). The role of person versus situation in life satisfaction: A critical examination. Psychological Bulletin, 130(4), 574600 .

Hennessy, K. (2005). Work-family conflict self-efficacy: A scale validation study. Masters of Arts, University of Maryland, USA.

Higgins, C.A., \& Duxbury, L.E. (1992). Work-family conflict: A comparison of dual-career and traditional-career Men. Journal of Organizational Behavior, 13, 389-411.

Ilies, R., Wilson K.S., \& Wagner, D.T. (2009). The spillover of daily job satisfaction on to employees family lives, the facilitating role of work-family integration. The Academy of Management Journal, 52, 87-102.

Ji, J., Xu, X., \& Rich, S.L. (2002). Determinants of family life satisfaction in reforming urban China. International Journal of Comparative Sociology, 43(2), 169-191.

Johansson, U., \& Bernspang, B. (2003). Life satisfaction related to work re-entry after brain injury: A longitudinal study. Brain Injury, 17, 991-1002.

Judge, T.A., \& Watanabe, S. (1993). Another look at the job satisfaction-life satisfaction relationship. The Journal of Applied Psychology, 78, 939-948.

Judge, T.A., Locke, E.A., \& Durham, C.C. (1997). The dispositional causes of job satisfaction: A core evaluations approach. Research in Organizational Behavior, 19, 151-188.

Kahn, R.L., Wolfe, D.M., Quinn, R., Snoek, J.D., \& Rosenthal R.A. (1964). Organizational stress: Studies in role conflict and ambiguity. Oxford, England: John Wiley.

Karabay, E. M. (2015). Sağlık personelinin iş stresi, iş-aile çatışması ve iş-ailehayat tatminlerine yönelik algılarının işten ayrılma niyeti üzerindeki etkilerinin belirlenmesi üzerine bir araştırma. Yönetim Bilimleri Dergisi, 13(26), 113-134. 
Karatepe, O.M. (2008). Work-family conflict and facilitation: implications for hospitality researchers. Handbook of Hospitality Human Resources Management, 12, 237-264.

Karimi, L. (2008). A study of a multidimensional model of work-family conflict among Iranian employees. Community. Work \& Family, 11(3), 283-295.

Keser, A. (2005). İş doyumu ve yaşam doyumu ilişkisi: Otomotiv sektöründe bir uygulama. Çalışma ve Toplum, 4, 77-96.

Kiecolt, J. (2003). Satisfaction with work and family life: No evidence of a cultural reversal. Journal of Marriage and Family, 65, 23-35.

Kinnie, N., Hutchinson, S., \& Purcell, J. (1998). Downsizing: is it always lean and mean. Personnel Review, 27(4), 296-311.

Köker, E. (1991). Normal ve sorunlu ergenlerin yaşam doyumu düzeylerinin karşılaştırılması. Yayınlanmamış Yüksek Lisans Tezi, Ankara Üniversitesi Sosyal Bilimler Enstitüsü, Ankara.

Kurtulmuş, M., \& Karabıyık, H. (2016). Farklılıkların yönetiminin öğretmenlerin örgütsel özdeşleşmesine ve işten ayrılma niyetine etkisi. International Journal of Human Sciences, 13(1), 1324-1341.

Lee, D. J., Yu, G. B., Sirgy, M. J., Singhapakdi, A., \& Lucianetti, L. (2018). The effects of explicit and implicit ethics institutionalization on employee life satisfaction and happiness: The mediating effects of employee evperiences in work life and moderating effects of work-family life conflict, Journal of Business Ethics, 147, 855-874.

Locke, E. A. (1976). The nature and causes of job satisfaction. In M.D. Dunnette (Ed.), Handbook of Industrial and Organizational Psychology (1297-1349), Chicago, IL: Rand McNally.

Lu, L., Huang, M.T., \& Kao, S.F. (2005). The bi-directional conflict of work and family: Antecedents, consequences and moderators. Research in Applied Psychology, 27, 133-166.

Mobley, W.H., Rodger, W.G., Herbert, H.H., \& Bruce, M.M. (1979). A review and conceptual analysis of the employee turnover process. Psychological Bulletin, $86,493-522$.

Netemeyer, R., Boles, J., \& McMurrian, R. (1996). Development and validation of work-family conflict and family work conflict scales. Journal of Applied Psychology, 81(4), 400-410.

Özbağ, K.G., \& Ceyhun, Ç.G. (2014). Does job satisfaction mediate the relationship between work family conflict and turnover? A study of Turkısh marine pilots. Procedia-Social and Behavioral Sciences, 140, 643-649. 
Özer, M., \& Karabulut Ö.Ö. (2003). Yaşl1larda yaşam doyumu. Turkish Journal of Geriatrics, 6(2), 72-74.

Özdevecioğlu, M. (2003). İş Tatmini ve yaşam tatmini arasındaki ilişskinin belirlenmesine yönelik bir araştırma. I.I.B.F. 11. Ulusal Yönetim ve Organizasyon Kongresi Bildirileri (693-711), Afyon Kocatepe Üniversitesi, 22-24 Mayıs 2003.

Özdevecioglu, M., \& Doruk, Ç.N. (2009). Organizasyonlarda iş-aile ve aile-iş çatışmalarının çalışanların iş ve yaşam tatminleri üzerindeki etkisi. Erciyes Üniversitesi İktisadi ve İdari Bilimler Fakültesi Dergisi, 33, 69-99.

Pattusamy, M., \& Jacob, J. (2017). The mediating role of family-to-work conflict and work-family balance in the relationship between family support and family satisfaction: A three path mediation approach. Current Psychology, 36, 812822.

Raza, B., Ali, M., Naseem, K., Moeed, A., Ahmed, J., \& Hamid, M. (2018). Impact of trait mindfulness on job satisfaction and turnover intentions: Mediating role of work-family balance and moderating role of work-family conflict. Cogent Business \&Management, 5, 1-20.

Rice, R.W., Near, J., \& Hunt, R. (1980). The job satisfaction-life satisfaction relationships: A review of emprical research. Basic and Applied Social Psychology, 1(1), 37-64.

Rode J.C., Rehg M.T., Near J.P., \& Underhill, J.R. (2007). The effect of work/family conflict on intention to quit: The mediating roles of job and life satisfaction. Applied Research in Quality of Life, 2, 65-82.

Qu, H. L, \& Zhao, X. (2012). Employees work-family conflict moderating life and job satisfaction. Journal of Business Research, 65(1), 2-28.

Shahpouri, S., Namdari, K., \& Abedi, A. (2016). Mediating role of work engagement in the relationship between job resources with turnover intention among female nurses. Apllied Nursing Research. 30, 216-221.

Siegel, P. A., Post, C., Brockner, J., Fisherman, A.Y, \& Garden, C. (2005). The moderating influence of procedural fairness on the relationship between worklife conflict and organizational commitment. The Journal of Applied Psychology, 90(1), 13-24.

$\begin{array}{lllll}\text { Soper, } & \text { D. (2019). Interaction } & \text { version } & \text { 1.7.2211 }\end{array}$ http://www.danielsoper.com/Interaction (Erişim tarihi: 30.05.2019)

Stolzenberg, R.M. (2001). It's about time and gender: Spousal employment and health. American Journal of Sociology, 107, 61-100.

Şimsek, Ş., Akgemci T., \& Çelik, A. (2003). Davranış bilimlerine giriş ve örgütlerde davranış. Konya: Adım Matbaacılık. 
Steiner, D.D., \& Truxillo, D. M.(1987). Another look at the job satisfaction-life satisfaction relationship: A test of the disaggregation hypothesis. Journal of Occupational Behavior, 8(1), 71-77.

Tekingündüz, S., Seçkin, M., Yaman, K., Türk, I., \& Aslan, S. (2016). Performans, iş tatmini ve iş-aile yaşam çatışması arasındaki ilişkiler. Uluslararası Sosyal Araştırmalar Dergisi, 9(42),1672-1679.

Turgut, T. (2011). Çalışmaya tutkunluk: İş yükü, esnek çalışma saatleri, yönetici desteği ve iş-aile çatışması ile ilişkileri, Atatürk Üniversitesi İktisadi ve İdari Bilimler Fakültesi Dergisi, 25(3), 155-179.

Turunç, Ö., \& Erkuş, A. (2010). İş-aile yaşam çatışmasının iş tatmini ve örgütsel bağl1lık üzerine etkileri: İş stresinin aracılık rolü. Selçuk Üniversitesi Sosyal ve Ekonomik Araştırmalar Dergisi, 13(19), 415-440.

Türker, Y. \& Çelik, K. (2019). Öğretmenlerde iş ve aile çatışmasının yaşam doyumu üzerindeki etkisinde iş doyumunun arac1 rolü. Hacettepe Üniversitesi Ĕgitim Fakültesi Dergisi, 34(1), 242-258.

Ugboro I.O., \& Obeng K. (2000). Top management leadership, employee empowerment, job satisfaction, and customer satisfaction in TQM organizations: An empirical study: Journal of Quality Management, 5, 247272.

Wang, Y. \& Peng, J. (2017). Work-family conflict and depression in Chinese Professional women: the mediating roles of job satisfaction and life satisfaction. International Journal Health Addiction, 15, 394-406.

Wayne, H. Jullie., Musisca, N., \& Fleeson, W. (2004). Considering the role of personality in the work family experience: Relationships of the big five to work family conflict and facilitation. Journal of Vocational Behaviour, 64, 108-130.

Weiss, D.J., Dawis, R.W., England, G.W., \& Lofquist, L.H. (1967). Manual for the Minnesota Satisfaction Quesitionnaire, (Minnesota studies in vocational rehabilitation No: 22). Minneapolis, University of Minnesota, Industrial Relations Center.

Wong, S., \& Ko, A. (2009). Exploratory study of understanding hotel employees' perceptions on work-life balance issues. International Journal of Hospitality Management, 28(2), 195-203.

Yıldız, S., Yalavaç, S., \& Meydan, C.H. (2013). Tükenmişliğin işten ayrılma niyetine etkisinde örgüte bağlılığın aracı rolü: Türkiye'deki Gümrük ve Ticaret Bakanlığı personeli üzerinde bir araştırma. Akdeniz İktisadi ve İdari Bilimler Fakültesi Dergisi, 26, 164-189.

Yüksel, İ. (2005). İş-aile çatışmasının kariyer tatmini, iş tatmini ve iş davranışları ile ilişkisi. Atatürk Üniversitesi Dergisi, 19(2), 301-314. 